\title{
AKUPRESURE SANYINJIAO POINT MAMPU MENURUNKAN INTENSITAS NYERI DISMENORHEA PRIMER
}

\author{
Heni Wijayanti ${ }^{1}$, Selviana ${ }^{2}$ \\ ${ }^{1}$ Prodi Sarjana Terapan Kebidanan, STIKes Karya Husada Semarang \\ E-mail:heniwijayanti55@gmail.com
}

\begin{abstract}
ABSTRAK
Dismenore adalah rasa sakit yang dirasakan oleh wanita ketika mesntruasi. Dismenore disebabkan oleh pelepasan berlebihan prostaglandin yaitu prostaglandin F2 alfa dari sel endometrium uterus. Banyak pengobatan dismenore yang telah berkembang di masyarakat baik terapi farmakologis maupun terapi nonfarmakologis.Salah satu terapi non-farmakologis adalah akupresur.Akupresur adalah penggunaan teknik sentuhan / kontak untuk menyeimbangkan saluran energi dalam tubuh atau Qi.Sanyinjiao Point adalah salah satu titik acupoint atau titik pertemuan limpa, hati dan saluran ginjal yang terletak dilimpa meridian.Tujuan : Mengetahui pengaruh Akupresur Terapi Sanyinjiao Point Terhadap Intensitas Nyeri Dismenore Primer di SMAN 11 Semarang.Metode Penelitian : Desain penelitian ini menggunakan Quasi Eksperiment dengan one group pre-test - post-test Design, populasi remaja putri yang mengalami dismenore sebanyak 35 orang. Teknik Sampling yang digunakan adalah accidental. Hasil Penelitian : Berdasarkan hasil penelitian 35 responden yang mengalami nyeri dismenorea pre intervensi dengan terapi akupresure Sanyinjiao Point mengalami nyeri berat 20 $(57,1 \%)$ responden dengan nilai rata-rata 3,57 dan post intervensi hampir seluruhnya adalah nyeri sedang sebanyak $21(61.1 \%)$ responden dengan nilai rata-rata 2.71 dengan $\mathrm{p}=$ value $0,000(\mathrm{p}<0,05)$. Simpulan: Ada pengaruh terapi akupresur Sanyinjiao Point terhadap intensitas nyeri dismenorea primer di SMAN 11 Semarang.
\end{abstract}

Kata kunci : Akupresure Sanyinjiao Point; Dismenorea

\section{ACUPRESSURE SANYINJIAO POINT IS ABLE TO REDUCE INTENSITY OF PRIMARY DISMENORE PAIN}

\begin{abstract}
Dysmenorrhea is the pain felt by women when menstruastion. Dysmenorrhea is usually caused by excessive release of certain prostaglandins, nemely the prostaglandin F2 alpha from uterus endometrium cells. Many treatment of dysmenorrhea that has developed in the community pharmacological and non- pharmacological therapy. One of non- pharmacologic therapy is acupressure. Acupresurre is a touch/ contact technique to balance the energy channels in the body or Qi. Sanyinjiao Point is one of acupoint or meeting point of spleen, liver and kidney channels located in the spleen meridian. This study was to find out the effect of Sanyinjiao Point acupressure therapy on the intensity of primary dysmenorrhea pain in SMAN 11 Semarang. The design of this study used quasi experiment with one group pretest - post test design, the population of young women who experience dimenorrhea in the month were 35 people.The sampling technique used was accidental.Based on the results of the study of 35 respondents who experienced dismenor pain pre intervention with Sanyinjiao Point acupressure therapy experienced severe pain $20(57.1 \%)$ respondents with an average value of 3.57 and almost all of the post intervention were moderate pain as much as $21(61,1 \%)$ respondents with an average value of 2.71 with the results of the value of $\mathrm{p}=$ value $0,000(\mathrm{p}<0.05)$. There is an effect of Sanyinjiao Point acupressure therapy on the pain intensity of primary dysmenor at SMAN 11 Semarang.
\end{abstract}

Keyword: Dysmenorrhea; Sanyinjiao Point Acupressure 


\section{Pendahuluan}

Rasa nyeri saat haid atau yang disebut dalam istilah medisnya dismenorea, ada dua jenis yaitu dismenorea primer dan dismenorea skunder.Dismenorea primer adalah nyeri haid yang terjadi sejak menarche dan tidak terdapat kelainan pada alat kandungan.Dismenore sekunder yaitu nyeri haid yang behubungan dengan kelainan anatomis yang jelas, kelainan anatomis ini kemungkinan adalah haid disertai infeksi, endometriosis, mioma submucosa, polip corpus uteri, endometriosis, pemakaian IUD.

Berdasarkan survey pendahuluan di beberapa SMA antara lain : SMA 15 Semarang, SMA 29 Semarang, SMA 2 Semarang dan SMAN 11 semarang. Didapatkan hasil pada bulan juni- oktober 2017 yang datang ke UKS dengan keluhan Dismenorea (nyeri menstruasi) di SMA 15 Semarang sejumlah 27 siswi, SMA 29 Semarang sejumlah 30 siswi, di SMA 2 Semarang sejumlah 32 siswi dan di SMA 11 Semarang sejumlah 35 siswi. Berdasarkan data diatas dapat disimpulkan bahwa nyeri dismenorea yang tertinggi pada bulan juni- oktober 2017 yaitu di SMA 11 Semarang sejumlah 35 siswi.

Hasil studi yang dilakukan di SMAN 11 Semarang pada bulan Oktober didapatkan 10 responden yang diteliti, 3 responden mengalami nyeri ringan sehingga dapat melakukan aktifitas sehari-hari seperti biasa, 3 responden pada saat menghadapi menstruasi mengalami nyeri sedang sehingga merasakan tidak nyaman seperti mual dan pusing mereka mengatasi ketidaknyamanan tersebut dengan cara minum obat pereda nyeri (asam mefenamat) dibagian perut dan sisannya 4 responden saat mengadapi menstruasi mengalami nyeri berat sehingga mengganggu aktifitas sehari-sehari. Dan juga berdasarkan hasil wawancara dengan petugas UKS (Usaha Kesehatan Sekolah) setiap bulannya ada beberapa remaja putri yang sering datang ke UKS dengan keluhan nyeri pada saat menstruasi.Mereka cenderung mengobatinya dengan istirahat dan minum obat pereda nyeri (Asam Mefenamat). Petugas UKS mengatakan belum pernah diadakan penelitian tentang masalah dismenorea sehingga penatalaksanaan dismenorea hanya dengan cara minum obat dan istirahat. Petugas UKS sangat mendukung dengan diadakannya penelitian tentang dismenorea ini, sehingga dapat menambah wawasan siswi-siswi di SMAN 11 Semarang dalam mengatasi dismenorea. Tujuan dari penelitian ini adalah untuk menganalisa pengaruh terapi akupresure Sanyinjiao Point terhadap intensitas nyeri dismenorea primer pada remaja sebelum dan sesudah dilakukan terapi akupresure Sanyinjiao Point di SMAN 11 Semarang. Hasil penelitian ini diharapkan dapat menambah pengetahuan cara mengatasi dismenorea dengan terapi akupresure Sanyinjiao Point serta dapat menerapkan terapi dirumah dengan media sosial berupa foto dan video. 


\section{Tinjauan Teoritis}

Menstruasi adalah Suatu proses pembersihan rahim terhadap pembuluh darah, kelenjarkelenjar, dan sel-sel yang tidak terpakai karena tidak adanya pembuahan atau kehamilan. Menstruasi diartikan juga sebagai pengeluaran secara periodic darah dan sel-sel tubuh dari vagina yang berasal dari dinding rahim wanita yang berlangsung sebulan sekali.

Dismenore merupakan suatu ketidaknyamanan yang dirasakan wanita pada saat menstruasi yang terjadi tanpa tanda - tanda infeksi atau pun penyakit panggul yang ditandai dengan nyeri kram pada abdomen bagian bawah yang dialami selama hari - hari pertama atau kedua saat menstruasi terjadi.Dismenore nyeri kram atau tegang di daerah perut, mulai terjadi pada 24 jam sebelum terjadinya pendarahan menstruasi dan dapat bertahan 24-36 jam meskipun beratnya hanya berlangsung 24 jam pertama.

Rasa nyeri saat haid atau yang disebut dalam istilah medisnya dismenorea, ada dua jenis yaitu dismenorea primer dan dismenorea skunder.Dismenorea primer adalah nyeri haid yang terjadi sejak menarche dan tidak terdapat kelainan pada alat kandungan.Dismenore sekunder yaitu nyeri haid yang behubungan dengan kelainan anatomis yang jelas, kelainan anatomis ini kemungkinan adalah haid disertai infeksi, endometriosis, mioma submucosa, polip corpus uteri, endometriosis, pemakaian IUD atau AKDR (alat kontrasepsi dalam rahim).Dampak yang terjadi jika dismenorea tidak ditangani dapat menimbulkan gangguan aktivitashidup sehari-hari, Retrograd menstruasi (menstruasi yang bergerak mundur), infertilitas (kemandulan), kehamilan atau kehamilan tidak terdeteksi, ektopic pecah, kista pecah, perfosi rahim jika menggunakan IUD dan infeksi.Hal ini sesuai dengan penelitian yang dilakukan oleh Nevy Norma Renityas (2012) tetentang efektifitas titik accupresure Li4 terhadap penurunan nyeri dysmenorrhoe pada remaja putri. Bahwa sebelum dilakukan intervensi sebagian besar mengalami nyeri berat 10 (45,5\%) responden dengan nilai rata-rata 3.32 dan setelah dilakukan hampir separuhnya mengalami nyeri sedang $12(54,5 \%)$ responden dengan nilai rata-rata 3.00 .

Penanganan dismenore pada umumnya dibagi menjadi 2 yaitu penanganan secara farmakologis maupun secara non farmakologis.Penanganan secara farmakologi seperti pemberian obat analgetik, terapi hormonal serta Terapi Dengan Obat Nonsteroid Antiprostaglandin.Sedangkan penanganan secara non farmakologi seperti istirahat cukup, olah raga teratur, kompres hangat, minum kunir asem dan dilakukan pemijitan.

Akupresur adalah suatu tindakan penekanan secara tepat pada titik khusus bagian tubuh untuk menurunkan nyeri, memberikan relaksasi dan mencegah atau mengurangi mual. 
Sanyinjiao Point ini merupakan titik yang digunakan untuk memperkuat limpa, mengembalikan keseimbangan Yin dan Yang, darah, hati, serta ginjal, dan memperlancar peredaran darah serta suplai darah.

Lokasi titik sanyinjiao ini terletak 3 cun di sisi atas mata kaki bagian dalam. Indikasi penyakit yang cocok pada titik ini adalah gangguan lambung dan limpa, abdomen tegang, diare, nyeri lambung, gangguan urologi dan ginekologi , nyeri perut , dan insomnia. Titik ini mempunyai keistimewaan yaitu tempat pertemuan tiga meridian yin kaki.

Penekanan dilakukan dengan ujung jari , pada saat awal harus dilakukan dengan lembut kemudian secara bertahap kekuatan penekanan ditambah sampai terasa sensasi yang ringan tetapi tidak sakit. Penekanan dapat dilakukan setiap kali pasien merasa nyeri yaitu 6 kali dalam 30 menit dengan durasi pemberian terapi 30 detik sampai 2 menit, setelah itu dilakukan evaluasi 30 menit kemudian.Hal ini sesuai dengan penelitain Mukhoirotin (2014) tentang Pengaruh akupresure pada titik sanyinjiau terhadap penurunan intensitas nyeri persalinan kala I fase aktif. Bahwa intensitas nyeri persalinan sebelum perlakuan menunjukan hampir seluruhnya nyeri berat dan apabila nyeri tidak diatasi bisa mempengaruhi kontraksi uterus melalui sekresi kadar katekolamin dan kotisol sehingga mempengaruhi durasi persalinan.

\section{Metode Penelitian}

Jenis penelitian ini adalah penelitian kuantitatif dengan desain Quasi Eksperiment.Penelitian ini bertujuan untuk mengetahui pengaruh terapi Akupresure Sanyinjiao Point terhadap intensitas nyeri dismenorea primer di SMAN 11 Semarang. Dilaksanakan pada bulan Oktober 2017 sampai Juni 2018.Sampel yang digunakan sebanyak 35 responden dengan purposive sampling.Instrument yang digunakan dalam penelitian ini menggunakan Skala NSR (Numerical Rating Scale), SOP pelaksanaan terapi Akupresure dan lembar observasi. Analisa data menggunakan uji Normalitas Shapiro wilks dan mempunyai nilai signifikansi $<0,05$ dan data berdistribusi tidak normal sehingga menggunakan uji Wilcoxon.

\section{Hasil Penelitian}

Hasil penelitian tentang pengaruh terapi akupresure sanyinjiao point terhadap intensitas nyeri dismenorea primer pada remaja putri di SMAN 11 Semarang dengan jumlah sampel 35 responden sebagai berikut : tingkat nyeri dismenorea pada remaja putrisebelum dilakukan intervensi sebagian besar mengalami skala nyeri berat yaitu 20 responden dengan 
nilai rata-rata 3,57 dan setelah dilakukan intervensi sebagian besar mengalami penurunan skala nyeri sedang yaitu 21 responden dengan nilai rata-rata 2.71 .

Hasil penelitian ini menunjukkan bahwa nilai skala nyeri dismenorea pada remaja putri pre intervensi rata-rata nilai 3,57 sebagian besar mengalami nyeri berat dan rata-rata nilai setelah dilakukan intervensi 2,71 sebagian besar mengalami nyeri sedang.

Penelitian ini serupa dengan penelitian yang dilakukan oleh Mukhoirotin tentang Pengaruh akupresure pada titik sanyinjiau terhadap penurunan intensitas nyeri persalinan kala I fase aktif. Bahwa intensitas nyeri persalinan setelah perlakuan menunjukan hampir separuhnya mengalami penurunan nyeri sedang sebanyak 7 (46.7\%) responden dengan nilai rata-rata 1,87 .

\section{Pembahasan}

Hasil penelitian menunjukkaan bahwa ada pengaruh terapi akupresure sanyinjiao point terhadap intensitas nyeri dismenorea primer pada remaja putri di SMAN 11 Semarang.Dismenorea terjadi karena endometrium dalam fase sekresi memproduksi prostaglandin berlebihan, prostaglandin (PGF-2) yang menyebabkan hipertonus dan vasokontriksi pada miometrium sehingga mengakibatkan iskemia, disintegrasi endometrium, perdarahan, dan nyeri.Secara umum nyeri digambarkan sebagai keadaan yang tidak nyaman, akibat dari luka paksa dari jaringan.Nyeri adalah pengalaman sensori dan emosional yang tidak menyenangkan akibat kerusakan jaringan yang aktual dan potensial yang teralokasi pada suatu bagian tubuh, jaringan seperti ditusuk-tusuk, panas terbakar, melilit, seperti emosi, perasaan takut, mual.

Ada beberapa cara untuk mengatasi gejala-gejala yang timbul akibat dismenorea yaitu dengan terapi medis dan non medis. Obat medis yang sering digunakan berupa analgesik dan anti inflamasi seperti asam mefenamat, ibuprofen dan antagonis kalsium, seperti verapamil dan nifedipin yang dapat menurunkan aktivitas dan kontraktilitas uterus.

Selain itu nyeri dapat ditangani dengan terapi non medis yang aman dilakukan dengan exercise, mand air hangat atau sauna, memakai buli-buli hangat, meditasi, serta dapat juga dengan pemberian suplemen, pengobatan herbal ala jepang, terapi horizon, terapi bedah, akupuntur dan akupresure.

Akupresur merupakan pengembangan dari teknik akupunktur yang memiliki tujuan sama yang digunakan untuk merangsang titik - titik yang ada di tubuh dan menekan hingga 
masuk ke system saraf dengan menggunakan gerakan dan tekanan jari yaitu jenis tekan putar, tekan titik dan tekan lurus. Prinsip dari akupresur ini dikenal sebagai adanya energi vital di tubuh (dikenal dengan nama Chi atau Qi di Cina dan Ki di Jepang). Aliran energy ini sangat mempengaruhi kesehatan, apabila aliran ini terhambat atau berkurang maka terjadilah sakit.Suplai dan aliran energy vital berjalan di saluran listrik tubuh yang tidak kelihatan yang sering disebut dengan meridian.Salah satu teknik untuk melancarkan energy vital adalah dengan akupresur yaitu menekan titik tertentu yang dikenal dengan acupoint dengan menggunakan telunjuk ataupun ibu jari untuk menstimulasi aliran energy di meridian.

Pemberian terapi akupresure pada saat dismenorea secara signifikan dapat menurunkan intensitas nyeri saat dismenorea, hal tersebut disebabkan karena efek penekanan di titik akupresure terkait dengan dampaknya terhadap produksi endorphin dalam tubuh. Pelepasan endorphin dikontrol oleh sistem saraf sensitif dengan nyeri rangsangan dari luar dan begitu dipicu dengan menggunakan tehnik akupresure akan mengintruksikan sistem endokrin untuk melepas sejumlah endorphin sesuai kebutuhan tubuh.

Penelitian ini serupa dengan penelitian yang dilakukan oleh Nevy Norma Renityas(2012) tentang efektifitas titik accupresure Li4 terhadap penurunan nyeri dysmenorrhoe pada remaja putri. Bahwa sebelum dilakukan intervensi sebagian besar mengalami nyeri berat $10(45,5 \%)$ responden dengan nilai rata-rata 3.32 dan setelah dilakukan hampir separuhnya mengalami nyeri sedang 12 (54,5\%) responden dengan nilai rata-rata 3.00. Hal tersebut menunjukkan terdapat perbedaan rata-rata anatara sebelum dilakukan intervensi dan setelah dilakukan intervensi. Hasil uji statistika $\mathrm{P}=0,001(\mathrm{P}<$ 0,05) menunjukkan ada pengaruh terapi akupresure sanyinjiau Li4 terhadap penurunan nyeri dysmenorrhoe.

\section{Kesimpulan}

Ada pengaruh terapi akupresur Sanyinjiao Point terhadap intensitas nyeri dismenorea primer di SMAN 11 Semarangdengan $\mathrm{p}$ value 0.000 .

\section{Saran}

Diharapkan masyarakat khusunya wanita untuk meningkatkan pengetahuan tentang mengatasi dismenorea dengan terapi akupresure sanyinjiao point serta dapat menerapkannya saat mengalami dismenorea primer. 


\section{Daftar Pustaka}

Andira Dita. (2010). Selak-beluk Kesehatan Reproduksi Wanita. Jogjakarta: Andi Offset Anurogo, Wulandari. (2011). Cara Jitu Mengatasi Nyeri Haid. Yogyakarta: CV. Andi Offset Arikunto, Suharsini. (2010). Prosedur Penelitian Suatu Pendekatan Praktek. Jakarta: Rineka Cipta

Charandabi, S.M. (2010). The Effect Of Acupressure At The Sanyinjiao Point (SP6) On Primary Dysmenorrhea In Students Resident In Dormitories Of Tabriz. Complementary Nursing Journal, 16: 1-19

Dinas Kesehatan. Kota Semarang Profil Kesehatan 2014. Semarang. Dinas Kesehatan Kota 2014

Fengge, A. (2012). Terapi akupresur manfaat dan pengobatan. Yogyakarta: Crop Circle Crop Hartono.(2012). Akupresure Untuk Berbagai Penyakit. Yogyakarta: Percetakan Andi Offset

Judha, M, Sudarti, \& Afroh Fauziah.(2012). Teori Pengukuran Nyeri dan Nyeri Persalinan. Yogyakarta: Nuha Medika

Laila, N. N. (2011).Kesehatan Reproduksi Remaja dan Wanita. Jakarta: Selemba Medika

Manuaba .(2009). Memahami Kesehatan Reproduksi.Jakarta : EGC

Marmi.(2015). Kesehatan Reproduksi. Yogyakarta: Pustaka Pelajar

Nasir, ABD, DKK. (2011). Metodologi Penelitian Kesehatan. Yogyakarta: Nuha Medika.

Nugroho, Taufan. (2014). Masalah Kesehatan Reproduksi Wanita. Yogyakarta: Nuha Medika

Prawirohardjo, Sarwono. (2014). Ilmu Kebidanan.Jakarta : PT. Bina Pustaka

Saryono dan Mekar Dwi Anggraeni. (2013). Metode Penelitian Kualitatif Dan Kuantitatif dalam Bidang Kesehatan. Yogyakarta: Nuha Medika

Sugiono. (2014). Metode Penelitian Kuantitatif Kualitatif dan $R \&$ D. Bandung: Alfabeta

Sulistyaningsih.(2011). Metodelogi Penelitian Kebidanan. Yogyakarta: Graha Ilmu

Ulfa, Maria. (2012). Kesehatan Reproduksi dan Keluarga Berencana untuk Mahasiswa Bidan. Jakarta: CV. Trans Info Media

Wiknjosastro. (2010). Buku Panduan Praktis Pelayanan Kesehatan Maternal dan Neonatal, Edisi I. Cet. 12. Jakarta : Bina Pustaka 